There are no doubt other examples where improvements are needed, but the above are among the most glaring. The present article does not aim at inducing any exact conformity to its suggestions, but rather at directing attention to the real diffculty in the invention of suitable names for new things, and to the importance of doing it carefully. It may also be hoped that the actual suggestions may be of service, so that those future writers who have not yet firmly established their own usages may be induced to accept at least some of them.

\title{
Control of the Prickly-pear in Australia
}

$\mathrm{T}$ HE control of the prickly-pears, Opuntia inermis and $O$. stricta, in Australia affords one of the most outstanding examples of the application of biological knowledge to economic purpose. It needs to be recollected that in 1925, about sixty million acres of grazing and farming land were known to be under infestation by prickly-pear in Queensland and New South Wales: the rate of spread of this scourge was stated to be reliably figured at almost one million acres a year. About fifty per cent of the infested territory was under dense prickly-pear, 3-5 ft. high, while the remaining area was affected by scattered infestations of varying intensity. To-day, the enormous rate of increase has been arrested, and less than ten per cent of the former great body of infestation survives: the whole of the primary pear in Queensland and much in New South Wales has broken down and collapsed. Approximately, twenty-five million acres of good land are now cleared and are being developed and brought under production.

The history of the campaign of control and eradication of prickly-pear has recently been briefly discussed by Mr. Allan P. Dodd, officer-incharge of prickly-pear investigations, Brisbane. All interested in the subject should read his important paper in the September issue of the Bulletin of Entomological Research $(27 ; 1936)$; a comprehensive history of the whole subject is promised in book form within two years time.

At the outset, the problem was how to eradicate a plant pest which had overrun, and rendered valueless, vast areas of territory. A pest, in fact, which could not be controlled by cultural, mechanical or chemical means, since the cost of widespread treatment by any of these methods rendered their application out of the question. The first steps towards applying biological methods of control were taken in 1912, and in 1920 the Commonwealth Prickly-pear Board came into being. This Board was charged with the study of prickly-pear in its natural home in America and the introduction, if possible, of insect or other enemies into Australia.
Since 192l, officers of the Board have visited most of the known prickly-pear regions of North and South America. Their investigations resulted in the discovery of about 145 species of insects which appear to be confined, in feeding habits, to prickly-pears and other Cactaceæ. Fungal and bacterial diseases also came in for investigation, but it was revealed that they did not afford much promise of direct utility, since many of these diseases were already established in Australia.

The Board's policy was based upon the conception that biological control offered best chance of success if a carefully selected group of species, working more or less in association, was established. A variety of promising species readily became adapted to Australian conditions and it was anticipated that their combined activities would, in course of time, result in gradual thinning out of the prickly-pear, in reduction of fruiting and consequently restriction of the spread of the pest.

It was quite unforeseen that the outstanding success evident to-day would have been effected by the agency of a single species of insect in the space of a few years. Nevertheless, this is what actually has happened, and the insect in question is the phycitid moth, Cactoblastis cactorum Berg. The fact is all the more remarkable for the reason that only 2,750 eggs (from the Argentine) of the insect were introduced into Australia, yet between 1926-30, about three thousand million eggs, laid by descendants of insects issuing from the original batch, have been distributed in the great pricklypear areas. The eggs are laid by the moth in 'sticks', averaging seventy-five eggs in each : these 'sticks' are readily collected and artificially attached to the cladodes of the host plant. The resulting larvæ are gregarious, internal feeders which tunnel in companies through the tissues of the plant, thus also providing for the ingress of disease organisms. In this way the prickly-pear ultimately becomes so completely destroyed that it is reduced to a rotting mass of pulp. The various insects, established prior to the Cactoblastis, have 
either been largely suppressed or their activities nullified owing to competition with its larvæ. It is only locally, and in relation to a few species of Opuntia of lesser importance, that the Cactoblastis has proved more or less ineffective. Such problems, however, are being dealt with effectively through the operations of other phytophagous insects including cochineal (Dactylopius) and cerambycid beetles.

In any campaign involving the repression of pest plants through the medium of introduced species of insects, the potential danger that such insects, in a new environment, may transfer their activities to other host plants cannot be neglected. In the case of prickly-pear control, elaborate biological tests as to the host plant range and preferences of such insects have been a feature of inestimable value. Doubtful species have been excluded and none so far introduced has betrayed any tendency, other than of a sporadic nature, to resort to hosts outside the species of Opuntia.

We hope to refer to prickly-pear control again at a later date when the promised book, recounting full details, becomes available.

A. D. Imms.

\section{Obituary}

Prof. T. M. Lowry, C.B.E., F.R.S.

$\mathrm{T}$ HOMAS MARTIN LOWRY, who died at Cambridge on November 2, came of an old Cornish family which had been long connected with the Methodist Church; he was born at Low Moor, Bradford, Yorks, on October 26, 1874, the second son of the Rev. E. P. Lowry, senior Wesleyan chaplain and staff officer at Aldershot. He was educated at Kingswood School, Bath, and thence passed to the Central Technical College, South Kensington, in 1893, with a Clothworkers' scholarship, and was ultimately awarded the fellowship of the City and Guilds of London Institute. From 1896 until 1913 he was an assistant to Prof. H. E. Armstrong ; in 190413, was lecturer in chemistry, Westminster Training College, and from 1913 until 1920 head of the chemical department in Guy's Hospital Medical School; in 1920 he was appointed to the newly created chair of physical chemistry in the University of Cambridge, a position which he held at his death. He married a daughter of the late Rev. C. Wood in 1904 and leaves two sons and a daughter.

During his long service with Prof. Armstrong, Lowry gained recognition for his delicate work in organic chemistry. The proficiency which he then acquired as a crystallographer expressed itself later in the aptitude which he displayed in applying exact physical methods of measurement to the solution of chemical problems; he developed a rare instinct for grasping the essentials of any subject which he attacked and for ensuring that the quantitative methods used were devoted to the measurement of something which was clearly defined. The vast mass of quantitative physical data collected by Lowry is thus not of merely ephemeral interest but will also provide useful working material for future generations of physical chemists.

During Lowry's first research work, he noted that the optical rotatory power of nitro- $d$-camphor solutions changes with lapse of time, and he early realized that this effect, which he termed mutarotation, arises from the tautomeric change of substances such as derivatives of camphor and of sugars. Mutarotation is dependent on the nature of the solvent, and the mutarotation of $d$-glucose can be arrested in such a hydroxylic solvent as cresol, or a basic one like pyridine, but proceeds almost too rapidly for measurement in a mixture of these solvents. Lowry thus showed that an amphoteric solvent is necessary as a catalyst for the mutarotation process, and built up his now well-known theory of prototropic change; it is largely on this work that the conception of dynamic isomerism advanced by van Laar became generally accepted.

Concurrently with his purely chemical work on mutarotation, Lowry studied the variation of rotatory power with wave-length, a sübject which had been much neglected since the death of Biot in 1862. He demonstrated the validity of Drude's equation for simple substances and expanded the equation so that it covered the anomalous rotatory dispersion of $d$-tartaric acid and the tartrates; this formed the subject of the Bakerian Lecture before the Royal Society by Lowry and Austin in 1921. Lowry's later determinations of the rotatory power of quartz, made on a column nearly half a metre in length, both in the visible and ultra-violet, furnished data of the highest precision by which again the validity of the Drude equation was established. He turned next from the optical rotatory power of transparent media to that of absorbent media and studied the Cotton effect; here he was able to develop equations which adequately express the dispersion throughout the absorption band. Whilst Lowry's main work in this field bore on optical rotatory power, he also studied other optical phenomena, and during recent years had initiated a series of investigations concerned with the refractive dispersion of organic compounds.

During the Great War, Lowry devoted himself to problems connected with high explosives and acted as director of shell-filling from 1917 until 1919; he did valuable service on the Trench Warfare Committee and the Chemical Warfare Committee and was an associate member of the Ordnance Committee at the time of his death. His war services gained him the C.B.E. and the Order of St. Maurice and St. Lazarus. He took the D.Sc. (London) in 1899 and held the honorary degree of M.A. (Cambridge) and doctorates of science of Dublin and Brussels; he became a fellow of the Royal Society in 1914. 